\title{
A Case Study on the Performance Evaluation of a Not-for-Profit Organization by the Balanced Scorecard Perspectives: Focused on the Korea Shipping Association
}

\author{
Hoo-Seok Pai* • Yong-John Shin** \\ * Dept. of Accounting, Kyungsung University, CPA and CISA \\ ** Division of Shipping Management, Korea Maritime University, CISA
}

\begin{abstract}
This paper aims to examine the use of the Balanced Scorecard in a not-for-profit organization (the Korea Shipping Association). The KSA has begun using the Balanced Scorecard paradigm in its strategic planning process. In this paper an overview is presented of the basic concepts of the Balanced Scorecard including the financial perspective, customer perspective, internal process perspective, and learning and growth perspective. The accounting system and its pros and cons of the KSA are then surveyed in terms of its performance evaluation. The application of the Balanced Scorecard approach to the KSA is discussed in detail. Implications in using the Balanced Scorecard are discussed. Finally, conclusions regarding the use of the Balanced Scorecard in a not-for-profit organization are presented. Through this paper, the comprehensive understanding of the performance evaluation for not-for-profit organizations as the KSA would be promoted.
\end{abstract}

Key words : Not-for-Profit Organization, Performance Evaluation, Balanced Scorecard, the Korea Shipping Association, Budgetary Reporting, Fund Accounting

\section{Introduction}

Since the introduction of the Balanced Scorecard approach by Kaplan and Norton, the methodology has been utilized in a number of for-profit and not-for-profit organizations. The literature is replete with examples of the successful implementation of the Balanced Scorecard approach, especially in for-profit organizations. In the for-profit sector, business entities have recognized that financial metrics by themselves are inadequate for measuring and managing their performances(Kaplan, 2001). Kaplan and Norton(1992, 1996) complemented the financial perspective with the other three perspectives: the customer, the internal process, and learning and growth. For-profit seeking corporations, the financial perspective provides clear long-run objectives(Kaplan 2001).

On the other hand, in the not-for-profit sector, the financial perspective provides a constraint rather than an objective. While the not-for-profits monitor spending and adhere to financial budgets, their success or failure is not measured by spending in relationship to budgeted amounts. According to Kaplan(2001), the typical not-for-profit has had difficulty placing the financial perspective at the top of the Balanced Scorecard. He suggests that the not-for-profits consider placing a mission objective at the top of their scorecard as the mission represents the accountability between the not-for-profit and society. He also suggests the not-for-profits expand the definition of who their customer is. As noted by Kaplan, a growing number of not-for-profits have begun using the Balanced Scorecard model(Martello et al., 2008).

This case study is a kind of the tentative research on performance measurement and evaluation by the Balanced Scorecard perspectives in public and private non-profit organizations. The Korea Shipping Association as a typical private non-profit organization has been also engaged in some public activities-terminal management and safety support etc. Consequently, as it became necessary to develop the performance measurement and evaluation for managing this complex organization, this study focuses on the subject to suggest an alternative approach to measure and evaluate appropriately the performance of the not-for-profit organization.

\section{The Performance Evaluation of Not-for-profit Organizations}

\subsection{The Accountability and Effectiveness of Not- for-profit Organizations}

Historically, organizations regardless of for-profit and

\footnotetext{
* Main author, hspai@ks.ac.kr 051)663-4418

** Corresponding author, yjshin61@hhu.ac.kr 051)410-4382
} 
not-for-profit placed a great deal of emphasis on financial measures in operating their organizations. According to Kaplan and Norton(1992) reliance on financial measures in management system is insufficient, as financial measures are lag indicators that reflect the outcomes from past actions. The Balanced Scorecard paradigm retains measures of financial performance and supplements these measures with factors that drive future financial performance. The Balanced Scorecard is based upon the cause-and-effect relationships of the financial and non-financial measures derived from the organization's strategy(Martello et al., 2008).

According to Cutt and Murray(2000), performance in for-profit organizations is generally defined from the perspective of stockholders around the central focus of profitability and corresponding return on stockholders' equity. It is clear what kinds of information are relevant, and, through generally accepted accounting principles(GAAP), how success is measured in terms of that information. There is, however, no such obvious unifying focus in public and private not-for-profit organizations which do not sell their products or services.

Some interesting attempts at systematizing the kinds of information to be included in a definition of performance in not-for-profit organizations appear in various literatures on accountability. There is broad agreement that the set of information presented about organizational performance should include both procedural and consequential components. The procedural components include financial information on the extent of compliance with authorities of various kinds. The consequential components include various attempts to develop a surrogate for profit in the form of evidence on 'value for money', usually defined to include the use of resources, i.e., efficiency, and the achievement of organizational purposes, i.e., effectiveness. In its work on comprehensive evaluation, the top management must define the scope of organizational performance which should be addressed in a comprehensive or broad-scope performance evaluation(Cutt and Murray, 2000).

The conceptual framework of the Balanced Scorecard was introduced by Kaplan and Norton(1992, 1993, 1996) for the purpose of designating, evaluating and measuring factors that drive an organization's performance.

\subsection{The Balanced Scorecard}

Kaplan and Norton's Balanced Scorecard concept seeks to provide managers with a set of performance metrics balanced between outcome measures and measures of the drivers of future outcomes(Kaplan and Norton, 1996b). It provides a framework for organizing strategic objectives into four perspectives. In each of the four perspectives quantitative measures are developed in order to operationalize the model. The four perspectives are as follows:

\section{Financial Perspective}

Profit-seeking organizations attempt to maximize their profit or stockholders' value. This is typically done through two approaches-increasing revenue and improving productivity. The basic intent is to improve the bottom-line. In a not-for-profit organization the emphasis is significantly different from that of a for-profit organization. The financial perspective might include a maximization of funding from outside sources instead of profit, or maintenance of fiscal stability. Certainly other factors could also be considered.

\section{Customer Perspective}

Kaplan and Norton indicate the core of any business strategy is the customer-value proposition which describes the unique mix of product, price, service, relationship, and image that a company offers. Accordingly, an organization must identify the customers it wishes to attract and the market segment in which it will compete. An organization differentiates its customer-value proposition. It selects from among operational excellence, customer intimacy, and product leadership. The customer perspective also identifies the intended outcomes from delivering a differentiated value proposition (Kaplan and Norton, 2001).

\section{Internal Process Perspective}

The internal process perspective involves the determination of the internal processes that will best affect the customers as well as the process improvements that will affect the financial objectives. In improving internal processes, there should be a connection between the overall strategy and the improvements. There should also be a determination of how the strategy is to be measured. According to Kaplan and Norton, in utilizing this approach the organization can frequently identify processes at which the organization must excel to meet its goals (Kaplan and Norton, 1996b; 2001).

\section{Learning And Growth Perspective}

The fourth category of the balanced scorecard is the learning and growth perspective, which has been identified as the foundation of any strategy. The learning and growth perspective involves a determination of employee capabilities and skills, technology, and a corporate climate needed to 
support a strategy. The human resources, technology and organizational climate must be aligned with the strategies within the other three perspectives giving the organization linkages among the four perspectives (Kaplan and Norton, 1996b; 2001).

\section{An Overview of the Korea Shipping Association}

\subsection{The Accounting System of the Korea Shipping Association}

The Korea Shipping Association was established more than five decades ago by a group of members who worked in the coastal shipping industry. This organization consists of both license-holding members(passenger transport companies, registrants of cargo transport firms) and associate members shipping brokerage firms, registrants of ship lending and management firms, harbor transportation service providers) based the related laws and regulations.

As a private not-for-profit organization, the KSA is a semi-governmental unit which is partly related to the public sector in the coastal shipping should design and maintain an original accounting system because it has some objectives and activities different from other for-profit organizations. For instance, the budgetary reporting and fund accounting are used in its financial report and accounting system. If the KSA might be considered as a non-profit society, but a nongovernmental organization, it should be applied to the GAAP for business entities as the FASB.1)

Moreover, the KSA is actually a kind of special-purpose government under the GASB Codification. ${ }^{2}$ Special-purpose governments include park districts, tollway authorities, school districts, and sanitation districts. GASB has categorized special-purpose governments as those that are engaged in governmental activities, business-type activities, and both governmental and business-type activities (Pai, 2004). Under the GASB, therefore, the KSA as a special-purpose government that are engaged in governmental activities and have more than activities must prepare both the government-wide statement and fund financial statements.

\subsection{The Budgetary Reporting and Fund Accounting}

The primary purpose of budgetary accounting is to control the availability of funds for expenditure by nonprofit organizations. Budgetary reporting should provide the information necessary to administer and monitor the budget. Within the nonprofit accounting system, information should be provided as to amounts authorized, amounts made available, and balances available for each fund or subunit. This budget information may be further defined to control each expenditure category within a fund or subunit.

In fact, the budgetary accounting of the KSA is inadequate and insufficient to measure and evaluate its budget-actual and variances. Its own budgetary reporting process has been developed and utilized by the association as well as other governmental organizations and non-profit institutions. Nonetheless, due to the discordance in the budgetary accounting occurring in the difference between the budget process and double-entry bookkeeping of most nonprofit organizations, the budgetary reporting process has been incompletely applied to control the budget by practicians. ${ }^{3)}$

Budgets are the most widely used method for control in not-for-profits. Fund accounting assists in budget control through providing information to enable managers to keep expenditures within allocation and demonstrate compliance with funding sources. That is a system of accounting used primarily by non-profit or government organizations. For these and other similar organizations, it is more important for them to keep a record of how their money was spent, rather than how it was earned, unlike corporations. Their accounting records take the form of a collection of funds, each fund having a distinct purpose, ranging from operating expenses to funding the various activities of the organization.

\section{General Fund}

In public sector accounting, the primary or catchall fund of a government, government agency, or nonprofit entity. It is similar to a firm's general ledger account, and records all assets and liabilities of the entity that are not assigned to a special purpose fund. It provides the resources necessary to sustain the day-to-day activities and thus pays for all administrative and operating expenses. When governments or administrators talk about balancing the budget, they typically

\footnotetext{
1) In case of the United States, the FASB has authority to establish accounting and financial reporting standards for all nongovernmental not-for-profit organizations, while the GASB has authority to establish accounting and financial reporting standards for all governmental units, including governmental not-for-profit organizations.

2) Generally, GASB Statement No. 34(1999) provides requirements that constitute the minimum required to be in compliance with GAAP.

3) The normal budget entries should be the reverse of financial entries; revenue entries are budgetary debits and appropriations to expenditure accounts are budgetary credits.
} 
mean balancing the budget for their general fund.

The general fund is the most significant fund in nonprofit accounting system. It accounts for all transactions not accounted for in any other fund. Revenues come many sources (regular membership fee, other annual fee, and charges for services, etc.), and the expenditures cover the general administrating functions.

\section{Special Revenue Fund}

In government accounting, the special revenue fund is a fund used to account for the proceeds of special revenue sources (other than special assessments, expendable trusts, or major capital projects) that are legally restricted to expenditure for specified purposes. Examples of special revenue funds are those established for the purpose of financing schools, parks, or libraries. In the case of the KSA, its special revenue funds include such accounts as mutual insurance fund, terminal management fund, safety support fund and crew payroll guarantee fund.

\section{The Balanced Scorecard Measurement of the Korea Shipping Association}

\subsection{Financial Perspective Measurement}

Generally, no matter what for-profit and not-for-profit organizations, the primary index of the financial perspective may be profitability. In the case of the KSA, the government-wide statement is available to measure it profitability as a performance. Table 1 below presents the some profitability ratios over 5 years.

Table 1 The profitability ratios over 5 years.

\begin{tabular}{|c|c|c|c|c|c|}
\hline Ratios & 2005 & 2006 & 2007 & 2008 & 2009 \\
\hline ROS & $7.12 \%$ & $7.42 \%$ & $7.27 \%$ & $7.77 \%$ & $5.50 \%$ \\
\hline ROA & $4.88 \%$ & $5.12 \%$ & $4.48 \%$ & $5.05 \%$ & $3.28 \%$ \\
\hline
\end{tabular}

Source: Calculated from financial disclosure online data of the KSA

The ROS, the net income to net sales ratio, of the KSA could be highly evaluated as compared with all industry average. The ROA, the ratio of net income to total assets, is similar to the level of all industry average.

As another financial index, growth rate generally refers to a organization's percentage change in assets, equity, revenue and net income over a given period. Table 2 exhibits the some growth rates over 5 years.
Table 2 The growth rates over 5 years.

\begin{tabular}{|c|r|r|r|r|c|}
\hline Items & \multicolumn{1}{|c|}{2005} & \multicolumn{1}{c|}{2006} & \multicolumn{1}{c|}{2007} & \multicolumn{1}{c|}{2008} & 2009 \\
\hline Assets & $9.15 \%$ & $9.69 \%$ & $26.20 \%$ & $6.45 \%$ & $20.49 \%$ \\
\hline Equity & $12.97 \%$ & $13.73 \%$ & $13.33 \%$ & $7.12 \%$ & $16.84 \%$ \\
\hline Revenue & $8.87 \%$ & $10.38 \%$ & $12.74 \%$ & $12.28 \%$ & $10.63 \%$ \\
\hline Income & $204.47 \%$ & $15.02 \%$ & $10.45 \%$ & $19.88 \%$ & $-21.71 \%$ \\
\hline
\end{tabular}

Source: Calculated from financial disclosure online data of the KSA

In terms of growth, the KSA displays eye-opening progress in its external size across the board. Nevertheless, the association had better observe the current downtrend of net income closely.

Furthermore, it is important for not-for-profit organizations to capture precisely their revenue structures of funds in terms of budgetary and financial goals. Table 3 reveals the revenue structures over 5 years.

Table 3 The revenue structures over 5 years.

\begin{tabular}{|l|r|r|r|r|r|}
\hline \multicolumn{1}{|c|}{ Funds } & \multicolumn{1}{c|}{2005} & \multicolumn{1}{c|}{2006} & \multicolumn{1}{c|}{2007} & \multicolumn{1}{c|}{2008} & \multicolumn{1}{c|}{2009} \\
\hline General & $6.03 \%$ & $5.42 \%$ & $5.45 \%$ & $4.51 \%$ & $4.08 \%$ \\
\hline Special & & & & & \\
\hline Mutual & $73.64 \%$ & $74.47 \%$ & $75.37 \%$ & $78.80 \%$ & $81.59 \%$ \\
\hline Safety & $9.68 \%$ & $9.69 \%$ & $9.29 \%$ & $9.03 \%$ & $7.84 \%$ \\
\hline Terminal & $10.50 \%$ & $9.72 \%$ & $9.33 \%$ & $7.40 \%$ & $6.24 \%$ \\
\hline Crew & $0.16 \%$ & $0.70 \%$ & $0.56 \%$ & $0.26 \%$ & $0.24 \%$ \\
\hline Total & $100.00 \%$ & $100.00 \%$ & $100.00 \%$ & $100.00 \%$ & $100.00 \%$ \\
\hline
\end{tabular}

Source: Calculated from financial disclosure online data of the KSA

According to Table 3, the mutual insurance fund is identified as the biggest sized fund in the KSA. Table 4 shows the revenue change rates over 5 years.

Table 4 The revenue change rates over 5 years.

\begin{tabular}{|l|r|r|r|r|r|}
\hline \multicolumn{1}{|c|}{ Funds } & \multicolumn{1}{c|}{2005} & \multicolumn{1}{c|}{2006} & \multicolumn{1}{c|}{2007} & \multicolumn{1}{c|}{2008} & \multicolumn{1}{c|}{2009} \\
\hline General & $18.03 \%$ & $-0.56 \%$ & $14.13 \%$ & $-6.04 \%$ & $-0.17 \%$ \\
\hline Special & & & & & \\
\hline Mutual & $8.68 \%$ & $11.86 \%$ & $14.75 \%$ & $18.79 \%$ & $14.15 \%$ \\
\hline Safety & $-1.32 \%$ & $10.81 \%$ & $8.65 \%$ & $10.39 \%$ & $-4.21 \%$ \\
\hline Terminal & $0.56 \%$ & $2.33 \%$ & $8.95 \%$ & $-9.89 \%$ & $-7.05 \%$ \\
\hline Crew & - & $381.10 \%$ & $-9.67 \%$ & $-46.26 \%$ & $1.15 \%$ \\
\hline Total & $7.40 \%$ & $10.60 \%$ & $13.39 \%$ & $13.62 \%$ & $10.24 \%$ \\
\hline
\end{tabular}

Source: Calculated from financial disclosure online data of the KSA

Similar to revenue, it is important for not-for-profit organizations to apprehend exactly their expenditure structures of funds in terms of budgetary and financial goals. Table 5 presents the expenditure structures over 5 years. 
Table 5 The expenditure structures over 5 years.

\begin{tabular}{|l|r|r|r|r|r|}
\hline \multicolumn{1}{|c|}{ Funds } & \multicolumn{1}{c|}{2005} & \multicolumn{1}{c|}{2006} & \multicolumn{1}{c|}{2007} & \multicolumn{1}{c|}{2008} & \multicolumn{1}{c|}{2009} \\
\hline General & $12.77 \%$ & $13.46 \%$ & $12.73 \%$ & $10.83 \%$ & $10.91 \%$ \\
\hline Special & & & & & \\
\hline Mutual & $67.65 \%$ & $66.63 \%$ & $68.04 \%$ & $72.46 \%$ & $75.25 \%$ \\
\hline Safety & $9.45 \%$ & $9.66 \%$ & $9.70 \%$ & $8.60 \%$ & $7.62 \%$ \\
\hline Terminal & $9.97 \%$ & $10.03 \%$ & $9.65 \%$ & $8.07 \%$ & $6.16 \%$ \\
\hline Crew & $0.16 \%$ & $0.23 \%$ & $(0.12) \%$ & $0.04 \%$ & $0.07 \%$ \\
\hline Total & $100.00 \%$ & $100.00 \%$ & $100.00 \%$ & $100.00 \%$ & $100.00 \%$ \\
\hline
\end{tabular}

Source: Calculated from financial disclosure online data of the KSA

As above, Table 6 represents the expenditure change rates over 5 years.

Table 6 The expenditure change rates over 5 years.

\begin{tabular}{|l|r|r|r|r|r|}
\hline \multicolumn{1}{|c|}{ Funds } & \multicolumn{1}{c|}{2005} & \multicolumn{1}{c|}{2006} & \multicolumn{1}{c|}{2007} & \multicolumn{1}{c|}{2008} & \multicolumn{1}{c|}{2009} \\
\hline General & $17.69 \%$ & $9.62 \%$ & $7.38 \%$ & $-4.02 \%$ & $13.89 \%$ \\
\hline $\begin{array}{l}\text { Special } \\
\text { Mutual }\end{array}$ & $7.49 \%$ & $2.41 \%$ & $15.97 \%$ & $20.19 \%$ & $17.43 \%$ \\
\hline Safety & $7.12 \%$ & $6.27 \%$ & $14.06 \%$ & $0.11 \%$ & $0.07 \%$ \\
\hline Terminal & $6.07 \%$ & $4.64 \%$ & $9.33 \%$ & $-5.66 \%$ & $-13.65 \%$ \\
\hline Crew & - & $44.51 \%$ & - & - & - \\
\hline Total & $8.69 \%$ & $3.99 \%$ & $13.56 \%$ & $12.85 \%$ & $13.08 \%$ \\
\hline
\end{tabular}

Source: Calculated from financial disclosure online data of the KSA

\subsection{Customer Perspective Measurement}

Traditionally, the KSA has two different type of customers. One is internal customer, i.e., license-holding and associate member, and another external customer, i.e., passenger and consigner using the coastal shipping. Concerning the consumer perspective, the intent is to improve the level of service in two respects. First, the KSA has strived to provide internal members satisfaction by closing the gap of unmet mutual insurance and fuel supply and improving access to service by the members. Second, the KSA has tried to improve the service quality of coastal shipping for external consumers by giving them terminal management and safety support. In support of achieving its internal consumer goals, the KSA has developed core measures within the operational perspective. Table 7 reveals the subscription rates of mutual insurance over 5 years.

The members will not take up their mutual insurance, if they do not receive satisfaction from the policy of the KSA. As the subscription rates of mutual insurance is a surrogate indicator with respect to customers satisfaction, the KSA could evaluate its performance by the measure in terms of the service consumer perspective.
Table 7 The subscription rates of mutual insurance over 5 years.

\begin{tabular}{|l|r|r|r|r|r|}
\hline \multicolumn{1}{|c|}{ Types } & \multicolumn{1}{c|}{2005} & \multicolumn{1}{c|}{2006} & \multicolumn{1}{c|}{2007} & \multicolumn{1}{c|}{2008} & 2009 \\
\hline Pssngr. & & & & & \\
\hline Members & $100.00 \%$ & $100.00 \%$ & $100.00 \%$ & $96.2 \%$ & $98.7 \%$ \\
\hline Ships & $93.9 \%$ & $94.2 \%$ & $93.0 \%$ & $89.3 \%$ & $90.6 \%$ \\
\hline $\begin{array}{l}\text { Crew } \\
\text { Members }\end{array}$ & $72.5 \%$ & $67.3 \%$ & $68.8 \%$ & $66.7 \%$ & $68.8 \%$ \\
\hline Ships & $67.8 \%$ & $65.0 \%$ & $67.2 \%$ & $65.8 \%$ & $66.3 \%$ \\
\hline Vessel & & & & & \\
\hline Members & $47.9 \%$ & $43.3 \%$ & $44.7 \%$ & $43.0 \%$ & $46.3 \%$ \\
\hline Ships & $55.0 \%$ & $53.4 \%$ & $58.2 \%$ & $57.0 \%$ & $58.9 \%$ \\
\hline Owner & & & & & \\
\hline Members & $21.1 \%$ & $22.1 \%$ & $22.7 \%$ & $23.0 \%$ & $26.2 \%$ \\
\hline Ships & $16.9 \%$ & $19.0 \%$ & $21.1 \%$ & $22.5 \%$ & $25.0 \%$ \\
\hline
\end{tabular}

Source: KNMU(2010), A Management Consultation of the KSA, Korea National Maritime Univ.

Further, the KSA has engaged in the operational service to supply two types of fuel for its members. The volume of supply is also a kind of the measure revealing customers satisfaction. Table 8 displays the supply volumes of taxation and tax exemption fuel over 5 years.

Table 8 The supply volumes of taxation and tax exemption fuel over 5 years.

(thousand $k l$ )

\begin{tabular}{|c|r|r|r|r|r|}
\hline Types & \multicolumn{1}{|c|}{2005} & \multicolumn{1}{c|}{2006} & \multicolumn{1}{c|}{2007} & \multicolumn{1}{c|}{2008} & \multicolumn{1}{c|}{2009} \\
\hline Tax Free & 677.1 & 655.9 & 669.4 & 642.6 & 656.1 \\
\hline Taxation & 21.6 & 18.9 & 16.9 & 16.5 & 17.9 \\
\hline
\end{tabular}

Source: KNMU(2010), A Management Consultation of the KSA, Korea National Maritime Univ.

\subsection{Internal Process Perspective Measurement}

The KSA knows that to reach its customer goals as well as to improve financial index, it must excel in its internal operation processes. Generally, most not-for-profit organizations have attempted to provide operational excellence by developing systems to effectively and efficiently deliver services in the natural environment and/or by developing a comprehensive management information system.

Specially, The KSA has been attempting to identify by statistics the 14 local branches' cost structure to be able to evaluate their efficiency in order to make decision about business opportunities. Table 9 lets readers see only the respective cost functions of 3 local branches by regression analysis. The cost functions of 9 remainders were not significant statistically. 
A Case Study on the Performance Evaluation of a Not-for-Profit Organization by the Balanced Scorecard Perspectives: Focused on the Korea Shipping Association

Table 9 The cost functions of the local branches

(thousand)

\begin{tabular}{|c|c|r|r|l|}
\hline Branches & Fixed Cost & Variable Cost & $t$-value & Prob. \\
\hline A & 61,184 & 63.76 & 1.9811 & 0.0523 \\
\hline B & 41,201 & 109.88 & 2.1096 & 0.0392 \\
\hline C & 13,660 & 16.9 & 1.9205 & 0.0597 \\
\hline
\end{tabular}

Source: KNMU(2010), A Management Consultation of the KSA, Korea National Maritime Univ.

By utilizing these cost functions, the KSA is able to improve the internal process of branches budgeting and then to enhance their operational efficiency. As to estimate and control their budgets by cost functions is important to heighten the level of internal process, the association should identify the cost structure of all local branches continuously.

\subsection{Learning and Growth Perspective Measurement}

Just as it is necessary to have operational goals to support its consumer and financial objectives, the KSA realizes it must have a workforce, technology and an environment conducive to achieving its operational goals. With great portion of its operating budget dedicated to employee wages and benefits, the KSA understands the importance of developing a motivated, prepared and satisfied workforce. In order to satisfy this strategic objective most not-for-profit organizations have attempted to increase staff competencies; to develop programs to recognize the efforts of employees; to provide personal growth opportunities within the organization for employees; and, to recruit, orient, manage, develop and retain employees.

Especially, The KSA also recognizes that to accomplish many of its goals, it must concentrate on the improvement of education and training. Table 10 illustrates the results of education and training in 2009.

Table 10 The results of education and training in 2009

\begin{tabular}{|l|r|}
\hline \multicolumn{1}{|c|}{ Education and Training } & Participants \\
\hline Advanced course to maritime policy & 1 \\
\hline Extended training overseas to underwriting & 1 \\
\hline Education for the certification of underwriter & 11 \\
\hline Correspondence schooling & 124 \\
\hline e-MBA course & 4 \\
\hline Education for underwriting practician & 34 \\
\hline Overall job training & 21 \\
\hline Orientation for new recruits & 5 \\
\hline Education for fuel supply practician & 20 \\
\hline Job training for safety supporter & 33 \\
\hline \multicolumn{2}{|c|}{ Total } \\
\hline
\end{tabular}

Source: KNMU(2010), A Management Consultation of the KSA, Korea National Maritime Univ.
Table 11 below indicates the education and training hours per employees in 2009 .

Table 11 The education and training hours per employees in 2009

\begin{tabular}{|l|r|r|}
\hline \multicolumn{1}{|c|}{ Positions } & Participants & average hours \\
\hline Class 1A & 9 & 70.44 \\
\hline Class 1B & 20 & 60.05 \\
\hline Class 2 & 34 & 51.09 \\
\hline Class 3 & 51 & 56.88 \\
\hline Class 4 & 15 & 47.20 \\
\hline Class 5 & 13 & 32.62 \\
\hline Technical post & 38 & 38.76 \\
\hline Total & 180 & 50.43 \\
\hline
\end{tabular}

Source: KNMU(2010), A Management Consultation of the $K S A$, Korea National Maritime Univ.

\subsection{Implications in Using the Balanced Scorecard}

The KSA has experienced a number of benefits with the implementation of the Balanced Scorecard. Perhaps the greatest benefit is the realization by personnel within the association that strategic planning is a significantly more encompassing process than merely looking at long-range planning. With the utilization of the Balanced Scorecard paradigm, individuals throughout the organization have become involved in focusing on the linkages between each segment of the KSA and the strategic plan. It is necessary to align each area of the KSA with the overall strategic objectives.

Another significant benefit concerns the focus on measurements or metrics within the association. It is extremely difficult and time consuming to develop metrics in not-for-profit organizations. However, with considerable effort, the association could begin to develop metrics that do provide linkages to the overall strategic plan.

The KSA could also start to focus on the importance of stressing the interrelationship among the four perspectives in the Balanced Scorecard model. This has enabled the individuals working in this non profit organization to stress things they had not previously even thought about. According to individuals working at the association, the benefits significantly outweigh the time requirements in utilizing the Balanced Scorecard.

\section{Conclusion}

The conceptual framework of the Balanced Scorecard has 
been implemented and utilized effectively for years in a large number of for-profit organizations. More recently, the model has been effectively utilized in not-for-profit organizations as well.

This study has described how the Balanced Scorecard approach has been implemented in an nonprofit organization. In implementing the Balanced Scorecard approach, the KSA has placed equal emphasis on the consumer perspective and the financial perspective. This equal focus is based upon the necessity of the association to carry out its primary mission for its internal members and external consumers as well as the necessity to advance financial indicators within this organization. The emphasis on both of these perspectives has become a necessity in order for the KSA to efficiently and effectively serve its members or customers. The implications of this study are listed below.

Firstly, while the use of the Balanced Scorecard in the long range planning process for the organization is relatively new, the process has been accepted by the management of the organization. For example, the challenge ahead for the KSA is to continue to develop outcome measures for the local branches within the association and tie these outcome measures to the strategic objectives of the association. It is recognized this is an extremely difficult process as their cost behaviors are not easily measurable.

Secondly, The formulation of outcome measures is a continuous development process. It is felt this process will definitely enhance the efficiency and effectiveness of the association in the long run. Additionally, in order to determine appropriately the key performance indexes for KSA, several activities of the organization should be analyzed carefully after confirming its vision and mission. This procedure might be important to examine the performance of not-for-profit organizations. Nevertheless, this study neglected the process due to the limitation of research's scope.

With conclusion, this paper reviewed a case of performance evaluation for not-for-profit organizations under the perspectives of the BSC. Through this study, the comprehensive understanding of performance evaluation in not-for-profit organizations such as the KSA would be promoted.

\section{References}

[1] Cutt, J. and V. Murray(2000), Accountability and Effectiveness Evaluation in Non-Profit Organizations, London: Routledge.
[2] Kaplan, R. and D. Norton(1992), "The Balanced Scorecard: Measures That Drive Performance," Harvard Business Review 70(1), pp. 71-79.

[3] Kaplan, R. and D. Norton(1993), "Putting the Balanced Scorecard to Work," Harvard Business Review 71(5), pp. $134-147$.

[4] Kaplan, R. and D. Norton(1996a), "Using the Balanced Scorecard as a Strategic Management System," Harvard Business Review 74(1), pp. 75-85.

[5] Kaplan, R. and D. Norton(1996b), The Balanced Scorecard, Boston, MA: Harvard Business School Press. 1996b.

[6] Kaplan, R. and D. Norton(2001), "Transforming the Balanced Scorecard From Performance Measurement to Strategic Management: Part I," Accounting Horizons 15(1), pp. 87-104.

[7] Kaplan, R.(2001), "Strategic Performance Measurement and Management in Nonprofit Organizations," Nonprofit Management and Leadership 11(3), pp. 353-370.

[8] KNMU(2010), A Management Consultation of the KSA, Korea National Maritime University.

[9] Martello, M., J. G. Watson, and M. J. Fischer(2008), "Implementing a Balanced Scorecard in a Not-For-Profit Organization," Journal of Business and Economics Research 6(9), pp. 67-80.

[10] Pai, H. S.(2004), "A Study on Introduction of the Budgetary Accounting System for Not-for-profit Organizations related to Maritime and Fisheries Sector in Korea," International Journal of Navigation and Port Research 28(7), pp. 593-600.

Received 28 January 2011

Revised 30 March 2011

Accepted 30 March 2011 